\title{
Enhancing Interest Among Senior Secondary Students in Expository Essay Writing in South East Nigeria: The Reciprocal Peer Tutoring Approach
}

\author{
Amuche .P Nnamani ${ }^{1} \&$ Josephine U. Akabogu ${ }^{1}$ \\ ${ }^{1}$ Department of Arts Education, University of Nigeria, Nsukka, Nigeria \\ Correspondence: Josephine U. Akabogu, Department of Arts Education, University of Nigeria, Nsukka, Nigeria. \\ E-mail: josephine.akabogu@unn.edu.ng
}

Received: January 11, 2020 Accepted: March 10, 2020 Online Published: March 22, 2020

doi:10.5539/gjhs.v12n5p38 URL: https://doi.org/10.5539/gjhs.v12n5p38

\begin{abstract}
The study focused on investigating the impact reciprocal peer tutoring teaching approach has in promoting interest among senior secondary school students in writing expository essay in Igbo -Etiti Local Government Area, South-East, Nigeria. The effect of gender in promoting interest in expository essay writing among senior secondary school students was also investigated. Two research questions and three null hypotheses guided the study. The study adopted a quasi- experimental design. 75 (32 males and 43 females) in two intact classes consisted of the sample for the study. Expository Essay Writing Interest Inventory (EEWII) which was face validated by four consultants was used as an instrument to data for the study. Mean, standard deviation and analysis of covariance (ANCOVA) were used to analyze the data collected. Results obtained revealed that reciprocal peer tutoring teaching approach was effective in promoting interest in expository essay among the students. The result also indicated that the variation in the mean interest scores of male and female students in expository essay was not significant. The interaction effect of gender and the teaching approach on mean interest scores of senior secondary school students in expository essay writing was also not significant. Hence, the researchers recommended that secondary school teachers should adopt this teaching approach for expository essay writing teaching in secondary schools.
\end{abstract}

Keywords: writing, expository essay, interest, gender, reciprocal peer tutoring

\section{Introduction}

One can never overemphasize the need for students to acquire good writing skills as it is foundational to their success in academics. Through writing, a student crafts, shapes and gives voice to ideas about a subject. It is a cognitive process that involves thinking and putting together of thoughts and ideas in acceptable format of the target language. Chukwuma and Otagburuagu (2002), remark that writing is one of the constant tasks that is demanded of students in schools. According to them, it is central to the study of English which is one of the compulsory subjects in Nigerian schools. Most examination questions in English and some other disciplines sometimes demand essay type answers; therefore, composing continuous prose either for an English language assignment or any other subject assignment demands the principle of good composition where one will be required to generate ideas and organize them into systematic and coherent essay. Ezema (2006) posits that writing is a common linguistic exercise which a lot of importance is attached. It is a demanding linguistic task which requires the writer to express his thoughts successfully even under examination condition. Muodumogu \& Unwaha (2013) revealed that proficiency in writing is the key and foundational to successes in global economy. However, Perin (2007) opined that good writing skill gives pleasure and joy to any one that acquires it. However, the absence of good writing skill in a student can also be very frustrating and annoying. A person is deemed a good writer if he or she is able to put down his thoughts and ideas in an organized and acceptable format for others to share. Similarly, poor writing skills mask one's actual capacity of expression, which in turn mask one's actual knowledge status (Muodumogu \& Unwaha 2013).

However, Marrion (2012) notes that acquisition of writing skill is necessary for educational success, but also one of the most complex skills to master. It is the hardest of all the language skills. Obasikene, Odo, Okwo \& Agbo (2005), also acknowledge that writing is the most sophisticated of the language skills because it is formal and 
requires high standard expression and skilful manipulation of ideas. According to them, writing begins gradually and practically from correct shaping of letters, perfect combination of letters, forming meaningful words to the more advanced form which is the ability to express ideas, narrate events, prove some points and paint some pictures through effective combination of words. This may probably explain the reason why the teaching of writing is not provided until after one acquires listening, speaking and reading skills. Generally, writing has been classified into four modes - descriptive, narrative, expository and argumentative (Connor, 1996, Richard and Schmidt, 2002 cited in Parviz \& Ali, 2009).

Expository essay has been implicated as the most frequently used form of writing (Parviz \& Ali 2009). It is the most common and the most important type of writing. For instance, in government and private offices, workers are usually asked to give a written description in form of reports and memorandum to get their colleagues and bosses informed about certain events or programs in the offices or at other levels. In schools also, often, teachers and other examination bodies put their students through some public examinations, quizzes, tests and home works for the purposes of evaluation. Writing exposition is demanded in every field, it cuts across every discipline. Term papers, Newspapers, Magazines, Articles, instructional manuals, textbooks, Encyclopedia, thesis, dissertation, scientific and literary subjects are products of expository essay. Expository essay is a type of essay that focuses attention on the explanation of an idea, an object, a thing, giving directions and order of doing things, namely: procedure and process. This type of essay generally interweaves with description and contains narrative elements, (Obasikene et al 2005). It defines analyzes, describes, compares, contrasts, evaluates and clarifies issues. One can therefore rightly argue that since expository essay interweaves with several forms writing, that any student that acquires skill in this very important form of writing can excel in narrative, descriptive and argumentative essays.

Nevertheless, Nnamani (2008) observes that secondary school students exhibit a lack of interest in learning expository essay writing skills and consequently do not write expository essay questions in WAEC English Examinations. The reason for students' lack of interest is probably because expository essay has a more complex structure than narrative, descriptive and argumentative essays. Expository essay does not have one specific writing format. Its writing format depends on the topic. The goal of interest in language learning can never be overemphasized. Interest accounts for students' successes or achievements in academics, be it Science or Arts. Ngonebu (2008) contends that most students that do not have an interest in language learning do not excel in language because they lack the zeal. It, therefore, implies that learners that are interested in language learning achieve well in it. Interest determines achievement. It is only when a learner is interested in learning a task that he or she may be engaged to learn. Interest is what ignites the zeal in a learner and continues propelling him or her until success is achieved (Subramaniam, 2009). Omeje (2002) observes that teaching and learning could be adjudged to have provided the desired result, if apart from helping students to pass an examination, also influence them to have zeal and continue to strive for success in that particular subject. Good instruction should, as a matter of fact, promote success among the students. Poor teaching strategy among other factors account for students' lack of interest in school subjects (Godpower-Echie \& Ihenko, 2017)

The teaching of essay generally in ESL classrooms according to Supong (2006) has been dominated by traditional teaching approach. In that approach, learners are made to copy the format of a model text while writing their own essay (Hassan \& Akhand 2010). Here, students are provided with samples of texts and will be expected to follow those standard samples and construct new pieces of writing. The approach is also called conventional method (Muodumogu \& Unwaha, 2013). This method emphasizes the students' output, and not how they come about the output or if they have mastered the writing skill. The traditional or conventional teaching approach has not helped in generating interest in students with respect to Expository essay. Palpadan, Salam and Ismail (2014) argue that it does promote writing creativity among the students, rather; the students are structured into a specific or particular writing style which cannot be applied in every expository essay writing topic. Igbokwe (2009) reveals that no teaching approach can be considered comprehensive or encompassing in all form. The author contends that the choice of approach one adopts depends on what one is teaching. Reciprocal peer tutoring approach is being tried here so as to determine its impact on interest of students in expository essay.

Reciprocal peer tutoring approach is a teaching approach that encourages students to take charge of teaching themselves under the guidance of the teacher. In this teaching arrangement, students take turns in being tutors and tutees. Students of the same class undertake the teaching of themselves through a process whereby one student among the group teaches other students. It involves students taking turns in teaching one another under the guidance of the class teacher. It enables each member of the tutoring process to participate as a tutor as well as a tutee (Griffin \& Griffin, 1995; Riggio, Fantuzzo, Connelly, \& Dimeff, 1999, Al-Hassan, 2003). The tutor 
tutee roles are beneficial to the students as it helps them to reap gains from preparing the material as well as in teaching which tutors get involved in, and also from instruction that tutees receive. The work of the tutor among other things includes mastering of the subject he teaches, this implies academic competence, the teacher reads in order to teach and be a more credible model. Obiunu (2009) asserts that: it helps the tutees to take more active roles in learning process. Among other benefits to the tutees according to the author is that it reduces anxiety in the learners. Students relax better with their fellow peer than with teachers or adults. This teaching approach allows students to promote academic achievement in one another. This is made possible because they choose their learning styles by themselves (Fantuzzo, Davies \& Ginsburg, 1995). It gives the participants the opportunity of monitoring their progress and assuming the responsibility for their learning.

Apart from teaching approach, the effect of gender in respect to interest of students in expository essay needs to be investigated. Gender has become an important variable that exert some influence in language learning. Gender can simply be referred to those societal created behavioral patterns and attributes judged appropriate by a specific culture for men and women, (World Health Organization, 2014). It is a socially constructed attitudes, responsibilities, roles and values invested or that are connected to individuals because they are males or females. Masoud, Seyyed \& Ali (2005) argue that there are differences between the language of a man and that of a woman and no education or social conditioning can wholly erase those differences. According to these authors, several educational research findings over the years have proved that students' academic interest is highly dependent on their gender. The PISA survey as cited in Maria (2013) reported that girls read more materials and use libraries more often than males. According to the report, females prefer more demanding text such as fiction whereas males were more likely to read comics and newspapers. The study conducted by Lietz as cited in Onuigbo (2008) revealed that students gender influences their reading interest. However, Uroko (2010) discovered in his research that students' interest in some language skills has nothing to do with their gender. The influence of gender on students' interest in expository essay will be determined in this research.

\subsection{Statement of the Problem}

The background to this research provided evidence that expository essay is very important and intertwines with other essay types. This by implication means that the knowledge of skills of writing this type of essay promotes success in several forms of essay. That notwithstanding, it was revealed that students exhibit low interest in expository essay probably because of its complex structure. The traditional teaching approach that is being used in teaching expository essay has been criticized for not fostering writing creativity among the students considering the structure of expository essay writing topics. This study seeks to ascertain whether reciprocal peer tutoring has an impact on students' interest in expository essay. Also, the effect of gender as it concerns the interest of female and male students in expository essay will be determined.

\subsection{Purpose of the Study}

Specially, this study seeks to ascertain the:

i. impact of reciprocal peer tutoring approach on students' interest in expository essay.

ii. effect gender has on students' interest in expository essay.

iii. interaction effect of approaches and gender on students' interest in expository essay.

\subsection{Research Questions}

i. What is the impact of reciprocal peer tutoring on the mean interest scores of students in expository essay?

ii. What effect does gender have on the mean interest scores of students in expository essay?

\subsection{Hypotheses}

The following null hypotheses were tested at 0.05 level of significance:

$\mathbf{H o}_{1}$. There is no significant difference in the mean interest scores of

students that were taught expository essay with reciprocal peer tutoring approach and their counterparts that were taught with traditional teaching approach.

$\mathbf{H}_{\mathbf{0 2}}$ : There is no significant difference in the mean interest scores of male

and female students in expository essay.

$\mathbf{H}_{\mathbf{0 3}}$. The interaction effect of approaches and gender on the mean interest scores of students in expository essay is not significant. 


\section{Methodology}

The research design was quasi-experimental design. It purposefully adopted a pre-test, post-test non-randomized control group design. It was carried out in Igbo-Etiti Local Government Area of Enugu State, South- East, Nigeria. A total of five thousand, three hundred and eighty-one $(3,381)$ senior secondary class two (SS 11) students in the Local Government constitute the study population. The sample for this study was seventy-five male and female (75) students that were drawn from two co-educational secondary schools in the Local Government area. Data was collected by the use of Expository Essay writing Interest Inventory (EEWII). The instrument was divided into two parts: part 1 sought personal data from the respondents in respect to their gender while part 2 is a 20 -item researchers' developed instrument that consists of 10 positive and 10 negative items with a four-point rating scale. It measured students' interest before and after the treatments. The instrument was subjected to face validation by consultants from the University of Nigeria, Nsukka. Cronbach Alpha was used to determine the reliability of the instrument and it yielded a reliability index of 0.75. Regular classroom English teachers served as research assistants to the researchers and were equally trained by the researchers themselves in areas of purpose of the study, treatment procedures, and procedures for administration and collection of the instruments.

Two sets of lesson plans on reciprocal peer tutoring approach and traditional teaching approach which had already been prepared and validated were handed to the research assistants, each according to the group handled. The research assistant in the reciprocal peer tutoring group helped in organizing the students in groups of fours. The grouping was done by using their SS1 first and second term results. This was to ensure that students of equal abilities were not lumped together. Before the treatments started, the research assistants administered the Expository Essay Writing Interest Inventory (EEWII) as a pre-test to the students. After, they collected them from the students and handed over to the researchers.

Thereafter, the research assistants commenced the treatment. Each with the lesson plan that was meant for that group. The specific objectives in the two lesson plans were the same; however, while one set of lesson plan adopted reciprocal peer tutoring approach, the other one adopted the traditional teaching approach. After the treatments for the two groups, the post-test was administered to the students, and when they finished, they were collected and given to the researchers. The data collected were analyzed using Mean, Standard Deviation and Analysis of Covariance (ANCOVA). Mean and Standard Deviation were used to answer the research questions while ANCOVA was used to test the null hypotheses at 0.05 level of significance.

\section{Results}

Results of this study were organized according to research questions and hypotheses that were used to guide the study.

\subsection{Research Question One}

What is the impact of reciprocal peer tutoring approach on secondary school students' mean interest scores in expository essay?

Table 1. Mean and standard deviation of interest scores of students that learnt expository essay using reciprocal peer tutoring approach and their counterpart that learned with traditional teaching approach

\begin{tabular}{lcccccc}
\hline \multirow{2}{*}{ Group } & \multicolumn{2}{c}{ Pre-test } & \multicolumn{3}{c}{ Post-test } \\
\cline { 2 - 8 } & $\mathrm{n}$ & Mean & SD & Mean & SD & Mean Gain \\
\hline Reciprocal Peer Tutoring & 35 & 50.28 & 5.96 & 73.22 & 9.40 & 22.94 \\
Traditional Teaching Approach & 40 & 49.72 & 6.13 & 58.35 & 7.47 & 8.63 \\
\hline
\end{tabular}

This table reveals that those that were exposed to reciprocal peer tutoring approach obtained mean interest score of 73.22 with a standard deviation of 9.40 at the post-test, these results vary with 50.28 and 5.96 which were got at pre-test stage as mean interest score and standard deviation respectively. It indicates also that students that learnt expository essay using traditional teaching approach obtained 58.35 and 7.47 at the post-test stage as their mean interest score and standard deviation respectively. These were also at variance with 49.72 and 6.13 which were obtained as mean interest score and standard deviation respectively at pre-test. 22.94 and 8.63 are the mean gain interest scores of the two categories of students and this shows that those students that were taught expository essay writing using reciprocal peer tutoring approach obtained a higher post mean interest scores than 
those that were taught using traditional teaching approach. However, 9.40 and 7.47 that were got as standard deviation at post-test by the two groups respectively show that reciprocal peer tutoring group varied much in their individual interest scores than the traditional teaching approach group.

\subsection{Research Question Two}

What is the impact of reciprocal peer tutoring approach on secondary school students' mean interest scores in expository essay?

Table 2. Mean and standard deviation of interest scores of students that learnt expository essay using reciprocal peer tutoring approach and their counterparts that learnt with the traditional teaching approach

\begin{tabular}{lcccccc}
\hline \multirow{2}{*}{ Gender } & Pre-test & \multicolumn{5}{c}{ Post-test } \\
\cline { 2 - 7 } & $\mathrm{n}$ & Mean & SD & Mean & SD & Mean Gain \\
\hline Male & 32 & 50.15 & 6.02 & 56.62 & 14.68 & 6.47 \\
Female & 43 & 49.86 & 6.09 & 60.93 & 19.54 & 11.10 \\
\hline
\end{tabular}

This table shows that 56.62 and 14.68 were obtained by male students as post-test mean interest score and standard deviation respectively which varies with 50.15 and 6.02 that were obtained as pre-test mean interest score and standard deviation respectively. On the other hand, the female students obtained 60.93 and 19.54 as post-test mean interest score and standard deviation against 49.86 and 6.09 that were their pre-test mean interest score and standard deviation. 6.47 and 11.10 which were obtained as mean gain scores by the male and female students respectively implies that the female students had higher post-test interest score than the male students. 14.68 and 19.54 that were obtained as post-test standard deviation by the male and female students respectively indicate also that the female students had higher individual interest scores than their male counterparts.

$\mathbf{H o}_{1}$ : There is no significant difference in the mean interest scores of students taught expository essay using reciprocal peer tutoring and those taught using conventional teaching method.

Table 3. Analysis of covariance of the effect of methods on students' interest in expository essay

\begin{tabular}{|c|c|c|c|c|c|}
\hline Source & Type III Sum of Squares & Df Mean Square & $\mathrm{F}$ & Sig. & Partial Eta Squared \\
\hline Corrected Model & $11087.410^{\mathrm{a}}$ & $4 \quad 2771.853$ & 14.266 & .000 & .449 \\
\hline Intercept & 1893.962 & 1893.962 & 9.748 & .003 & .122 \\
\hline Pre-test & 420.411 & 420.411 & 2.164 & .146 & .030 \\
\hline Treatment & 7977.100 & 7977.100 & 41.057 & .000 & .870 \\
\hline Gender & 759.521 & 1759.521 & 3.909 & .052 & .053 \\
\hline Treatment * Gender & 152.264 & $\begin{array}{ll}1 & 152.264\end{array}$ & .784 & .379 & .011 \\
\hline Error & 13600.536 & 70194.293 & & & \\
\hline Total & 304007.000 & 75 & & & \\
\hline Corrected Total & 24687.947 & 74 & & & \\
\hline
\end{tabular}

a. R Squared $=.449$ (Adjusted R Squared $=.418$ ).

This table reveals that the probability associated with the calculated value of $F$ (41.057) for the impact of reciprocal peer tutoring approach and traditional teaching approach on the interest of students in expository essay is 0.000 . Since the probability value of 0.000 is below the 0.05 level of significance $(p<0.05)$, the null hypothesis was not accepted, which means that there is a significant difference in the mean interest scores of students that were taught expository essay with reciprocal peer tutoring approach and those that were taught with traditional teaching approach in favour of those that were exposed to reciprocal peer tutoring. Apart from that, the partial Eta Square value (effect size) of 0.870 indicates that reciprocal peer tutoring approach exerts influence on students' interest in expository essay. 
$\mathbf{H o}_{2}$ : There is no significant difference in the mean interest scores of male and female students in expository essay.

Table 3 reveals that the probability associated with the calculated value of $F$ (3.909) for the effect of gender on the interest of students in expository essay is 0.052 . Since the probability value of 0.052 is greater than the 0.05 level of significance $(\mathrm{p}>0.05)$, the null hypothesis was accepted. Thus, there is no significant difference in the mean interest scores of male and female students in expository essay.

Ho $:$ There is no significant interaction effect of methods and gender on mean interest scores of students in expository essay.

Table 3 indicates that the probability associated with the calculated value of $F(.784)$ for the interaction effect of teaching approaches and gender on students' interest in expository essay is 0.379 . Since the probability value of 0.379 is greater than the 0.05 level of significance $(\mathrm{p}>0.05)$, the null hypothesis was not rejected, which implies that there is no significant interaction effect of approaches and gender on the students' mean interest scores in expository essay.

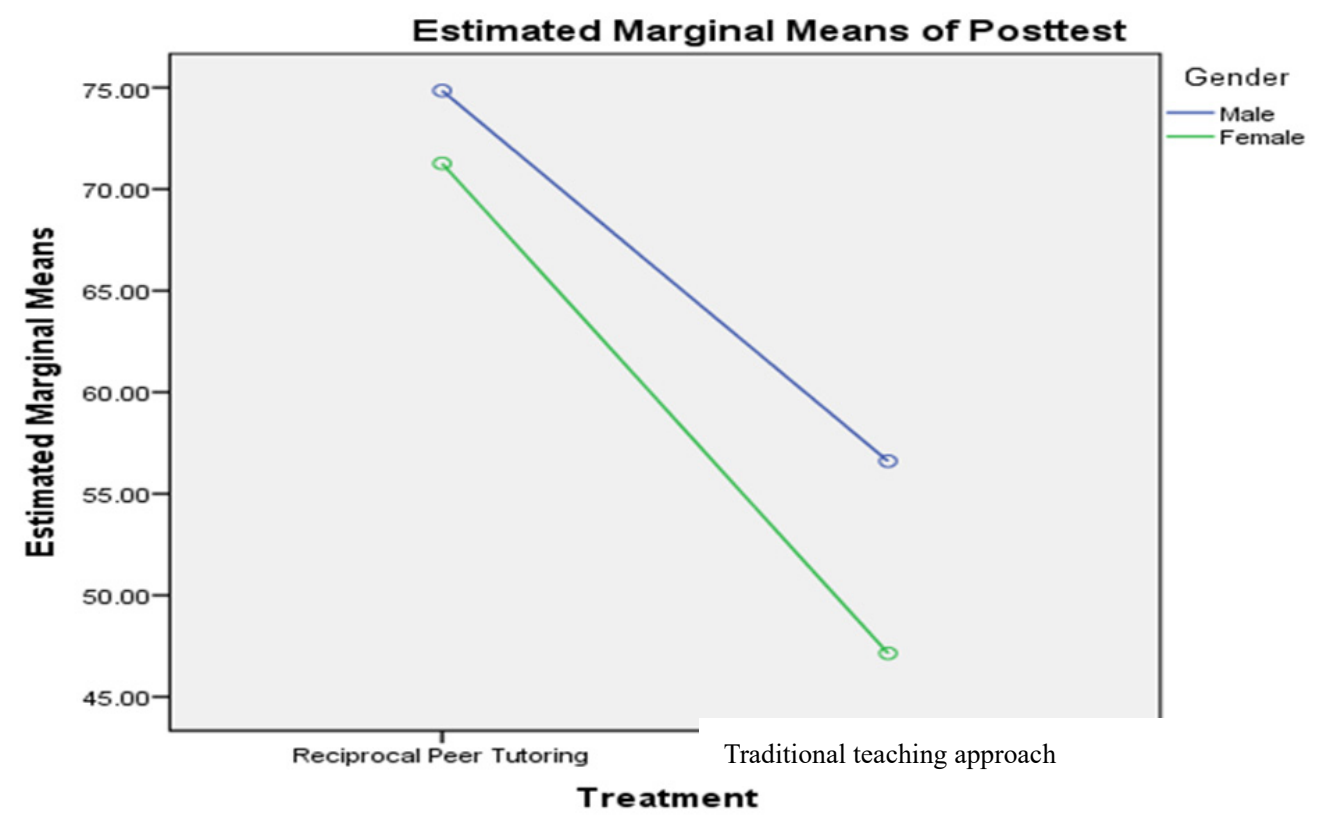

Covariates appearing in the model are evaluated at the following values: Pretest $=49.9867$

Figure 1. Plot of the interaction effect of methods and gender on students' interest in expository essay

The parallel lines inside the plot show that methods and gender cannot interact to affect the students' interest in expository essay.

\section{Discussion of Results}

It was indicated by the findings of this research that reciprocal peer tutoring approach had an impact on students' interest in expository essay. The students that were taught expository essay with reciprocal peer tutoring approach obtained mean interest scores that were higher than their counterparts that were taught with traditional teaching approach. This result confirmed the assertion made by Igbokwe (2009) that there is no best all-round approach but some approach may be better than others in teaching a particular skill. The result agrees with the findings of Uroko (2010) which revealed that this approach promotes students interest in some language skill.

It was also revealed by the result that there was no significant difference in the mean interest scores of male and female students that were taught expository essay writing with reciprocal peer tutoring approach and their counterparts that were taught the same type of essay writing with traditional teaching approach. This implies, therefore, that gender does not affect the interest of students in expository essay. The result disagrees with the findings of Lietz as cited by Onuigbo (2008) which revealed that gender directly influences students' interest.

The fact that the interaction effect of the treatments and gender was not significant shows that gender was not a factor in expository essay writing interest of students exposed to reciprocal peer tutoring. 


\section{Conclusion and Recommendation}

The results of this study revealed that reciprocal peer tutoring approach had a positive impact on the interest of students in expository essay writing. Thus, the students who were taught expository essay writing using the approach obtained higher mean interest scores than those taught using traditional teaching approach. Also, it was indicated by the result that gender did not influence the interest of students in expository essay writing. Now, considering these revelations made by this study, the researchers recommended that: secondary school teachers should adopt this approach for teaching expository essay writing in the secondary schools, that curriculum developers should consider the inclusion of reciprocal peer tutoring approach as one of the innovative teaching approaches for expository essay writing, that secondary school English textbook writers should include it as one of the teaching approaches for expository essay writing.

\section{Competing Interests Statement}

The authors declare that there are no competing or potential conflicts of interest.

\section{References}

Al-Hassan, S. M. A. (2003). Reciprocal peer tutoring effect on high frequency sight word learning, retention and generation of first and second grade of urban elementary school students. (Ph.D Thesis. Ohio State University). Retrieved on 24/12/15 from https:llet.ohiolink.edu/tetd/serd-file?...

Bakare, J. (2009). Effect of reciprocal peer tutoring on the academic achievementof students in electronics technology in technical colleges of Ekiti State. (Unpublished Ph.D thesis, Department of Vocational Education, University of Nigeria, Nsukka).

Chukwuma, H., \& Otagburuagu, E. (2002). English for academic purposes. Lagos: Africana Feb publishers.

Ezema, P. A. (2006). Essay writing techniques. In Onuigbo, S. (ed), Essay and Literary Concepts in English, 1929

Fantuzzo, J. W., Davies, G. Y., \& Ginsburg, M. D. (1999). Effect of parents' involvement in isolation or combination with peer tutoring on self concept and Mathematics achievement. Journal of Educational Psychology, 87, 272-281. https://doi.org/10.1037/0022-0663.87.2.272

Godpower-Echie, G., \& Ihenko, S. (2017). Influence of gender on interest and academic achievement of students in integrated science in Obio Alepo Local Government Area of Rivers state. European Scientific Journal, 272-279. https://doi.org/10.19044/esj.2017.v13n10p272

Griffin, M. M., \& Griffin, B. W. (1995). An investigation of the effects of reciprocal peer tutoring on achievement, self-efficacy, and test anxiety. Proceedings of the annual meeting of the national consortium for instruction and cognition, USA (Eric Document Reproduction Service No. ED3883756).

Hasan, K., \& Akhand, M. (2010). Approaches to writing in EFL/ESL contexts:Balancing product and process in writing class at tertiary level. Journal of NELTA, 15(12), 77-88.https://doi.org/10.3126/nelta.v15i1-2.4612

Igbokwe, U. L. (2007). Effects of the cognitive academic language learningapproach (CALLA) on students' achievement in essay writing (Unpublished Ph.D Thesis). Department of Arts Education, University of Nigeria, Nsukka.

Masoud, Z., Seyyed, A. K., \& Ali, K. (2013). The effect of gender on language learning. Journal of Novel Applied Sciences, 1124-1128. https://doi.org/10.1007/978-1-4020-8265-8_100599

Maria, D. C. (2013). Gender difference in reading cooperation achievement inEnglish as a foreign language in compulsory secondary education, Tejuelo, 17, 67-84. Retrieved from https://dianet.unirioja.es/.../4353124pdf

Mario, T. (2012). Writing in first and second language. Empirical studies on test quality and writing process. Retrieved from https://dspace.library.uu.nl-weijen

Muodumogu, C. A., \& Unwaha, O. U. (2013). Improving students' achievement inessay writing: What will be the impact of mini-lesson strategy? Global Advanced Research Journal of Arts and Humanities (GARJAH), 2(6), 111-120.

Ngonebu, L. C. (2008). Fundamental of second language learning. Nsukka: Afro-Orba Publications.

Nnamani, A. P. (2008). Essay \& letter writing for schools and colleges. Enugu:Liben Publishers

Obasikene, J. I., Agbo, B. O., Odo, S. S., Okwor, S. O., \& Agbo, W. O. (2005).Effective communication English: 
A practical approach. Enugu: New Generation Books.

Obiunu. J. J. (2009). The interactive effect of two treatments on parental typology of adolescent students in their

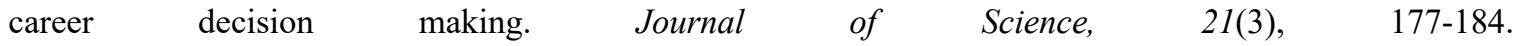
https://doi.org/10.1080/09718923.2009.11892768

Omeje, H. O. (2002). Effect of instructional building model on students' performance and interest in technical drawing. International Journal of Arts and Technology, 2(1) 85-86.

Palpadan, S., Salam, A., \& Ismail, F. (2014). Comparative analysis of processversus product approach of teaching writing in Malaysian schools: Review of literature. Middle East Journal of Scientific Research, 22(6), 7870795. Retrieved on 02/03/2016 from www.idosi.org/mejsr/mejsr22(6)14/

Perin, D. (2007). Best practices in teaching writing to adolescents in S., Graham, C. A. Mac Arthur, \& J. Fitsgerald (Eds.), Best practices in writing instruction (202-221). New York: the Guilford Press.

Riggio, J. C., Fantunzzo, J. W., Connelly, S., \& Dimeff, L. A. (1991). Reciprocal peertutoring: a classroom, strategy for promoting academic and social integration in undergraduate students. Journal of Social Behavior and Personality, 6(1), 90-109.

Subramanian, P. R. (2009). Motivational effect of interest on students' engagement and learning in physical education. Retrieved from www.scientificamerica.com/article/reading-paperscreen

Supong, T. (2006). Approaches to teaching second language writing. Language Institute Journal, 1(3), 1-26.

World Health Organization (WHO). (2014). Gender: Definitions. Retrieved on Feb, 2014 from www.who.int/topics/gender/en/

\section{Copyrights}

Copyright for this article is retained by the author(s), with first publication rights granted to the journal.

This is an open-access article distributed under the terms and conditions of the Creative Commons Attribution license (http://creativecommons.org/licenses/by/4.0/). 